\title{
Human Capital Investment: Building an App for That
}

\author{
Matthew M. Ross \\ Western Michigan University
}

\author{
A. Michelle Wright \\ Wright Research LLC
}

\author{
Simon N. Peffers \\ Supranational LLC
}

This paper outlines the development of a prototype application to estimate the human capital investment of education-career selections. We explain the need to deliver the right information, to the right person, at the right time using a customizable, individualized, just-in-time format. We illustrate how a collaboration between academia and FinTech might leverage the power of distributed expertise to support human capital investment planning via robo-advising. With 112 research-based default parameters, the application can provide detailed financial estimates in seconds. The prototype includes an interface to customize 12 key parameters allowing for extensive exploration of career and education pathways. We illustrate technical elements, the complexity of comprehensive personal financial projections, psychological obstacles, the potential for agency conflict, and balancing academic rigor with user experience. We also offer some insight into challenges and opportunities of this pre-seed venture.

Keywords: career planning, consumer sovereignty, personal finance, robo-advice, technology, employment

\section{INTRODUCTION}

Why is there so much conflicting information about human capital investment? Is college the "right" decision with many students actually borrowing too little to finance their college path (Avery \& Turner, 2012)? Or, as Caplan (2018) laments, is "there is way too much education" with "typical students burning through thousands of hours of material that neither raises their productivity nor enriches their lives" (pp. 2$3)$ ? Extant research in this area is growing, yet tends to focus on population-level decision making and is of limited use to guide individuals (e.g., Abel \& Deitz, 2014; Autor, 2014; Heckman \& Letkiewicz, 2021; Lobo \& Burke-Smalley, 2017). Given much population-level information, yet persistent confusion, we hypothesize that challenges stem from a lack of individualized information. Motivated by this concern, we outline a prototype human capital investment application developed by an academic-FinTech collaboration and challenges associated with a pre-emergence venture in this arena. 


\section{LITERATURE REVIEW AND MOTIVATION}

\section{Why the Reluctance to Address Human Capital Investment?}

Studying and quantifying individual human capital investment is challenging. Unlike most other capital, a human capital investment is irreversible, collateralized with flesh, and generates returns via the generally opaque labor market. Indeed, the contingent nature of human capital does not lend itself to inclusion on a balance sheet (Washer \& Nippani, 2004). Given these challenges, researchers may resort to a dichotomous approach to human capital (i.e., present or absent; see Siepel et al., 2017) or as perceived capability (i.e., entrepreneurial start-up self-efficacy, see Brush et al., 2017) rather than attempt to quantify the actual "value" of human capital. Even discussion of human capital - linking financial value to human value - can elicit strong emotions.

Perception of a robo-advising tool for human capital investment is also an important consideration. Some will view human capital investment robo-advising as a paternalistic device - a means of sorting the "haves" from the "have nots"-furthering inequality instead of decreasing it. Big data algorithms intended to aid human decision making are now criticized for creating disparities in health care (Obermeyer et al., 2019), access to credit (Natarajan \& Nasiripour, 2019), data privacy (Hayes et al., 2020), and even parental rights (Eubanks, 2018). Given these considerations, a robo-advising platform providing information about human capital is likely to face criticism.

Much resistance may also arise from the very organizations most capable of guiding human capital investment - universities. Building human capital is a core function of these institutions, yet the financial rewards to human capital investment vary widely by discipline (Abel \& Dietz, 2014; Webber, 2014). There exists substantial potential for agency conflict, both from administrators and faculty members, when institutions offer programs promising high variance of net present value (NPV). Both individuals and institutions may resist attempts to quantify the returns to human capital investment. Indeed, a grant reviewer for the current application bluntly stated, "Perhaps this will help some people not choose degrees that have no chance of paying back investment, but that will just kill the arts programs." As such, faculty entrepreneurs in this area may adopt an "insurgent" mentality whereby the disclosure of the NPV of a chosen degree becomes an issue of social justice and social sustainability (Muñoz \& Dimov, 2015).

Finally, university technology transfer may compound this potential agency conflict around userfocused human capital investment applications. Faculty work within a university ecosystem that must support entrepreneurial activities in order for research output to emerge into the marketplace (Thomas et al., 2020). Specifically, research outputs are owned, at least in part, by the originating university and must be developed with the support of the university technology transfer office. However, capabilities and styles of tech transfer offices vary widely (Weckowska, 2015). Even under the best of circumstances, there exists friction between the research-focused faculty, the commercialization-focused tech transfer office, and the enrollment-focused administrators within the university.

\section{Research Goals}

Our goal is a dynamic, applied model to address the most important financial decision facing young people. First, we search for a balance between simplistic user-friendly calculators with limited capacity, versus complex academic models that are designed for research rather than for users. The tool should be agnostic regarding education-career pathways in strictly providing financial projections. Meeting this goal would provide the right information to the user. Second, the model should allow users to employ editable default parameters as they consider their financial future. Research-based parameters are critical in providing users with appropriate benchmark values, while editability acknowledges the individual attributes of the right person. Lastly, the application should be consistently and easily accessible with just-in-time delivery to facilitate information at the right time. In the simplest form, we view the challenge as striking a balance in providing the right information to the right person at the right time. 


\section{Right Information}

Individuals making human capital investment decisions are often confused about the direct costs of their investment (Velez \& Horn, 2018) and legislative mandates to clarify college costs have been ineffective with many college websites still omitting critical information in their tuition calculators (Perna et al., 2021). Even if one can determine direct costs, other information is so difficult to coordinate that academic papers often omit key human capital investment variables (e.g., unemployment rates, taxes, Social Security). The sheer amount of information often results in over-weighting some aspects of the investment decision (i.e., college tuition) while under-weighing others (i.e., university graduation rates) (LaFave et al., 2018; Paulsen \& St. John, 2002). Rather than attempting to distill a parsimonious model, we model in detail applying researched default parameters. This approach allows an individual to begin with average and then customize to their desire and ability. To capture the greatest value from this model, a user should be able to edit parameters based upon their own situation. Verified and accessible databases are available for a majority of the key parameters to establish credible default values. For example, median salary for particular jobs is available via application programming interface (API) from the Bureau of Labor Statistics. We contend that the primary utility and market potential of an applied model flows from the ability to customize at an individual-level. From a technology angle, a human capital investment planning tool could be standalone and useable without professionals. However, from a practical angle, robo-advising platforms are often difficult to navigate (Bartlett \& McCarley, 2019). A personal finance professional, instructor, or a similarly trained individual following an established framework could be of great value in guiding the use of an application to estimate human capital investment options (Wright \& Ross, 2021).

\section{Right Person}

While no shortage of research exists about the "average" college student, individuals often find it difficult to apply average information to their own circumstances (Savage, 2009). Yet some key variables in human capital calculations are critical to personalize. For example, whether or not college is a "good" investment depends largely on one's individual discount rate and the expected number of periods after graduation. With issues so sensitive as putting a price on patience via the discount rate and confronting mortality via an estimate for remaining periods, one might imagine that some people would refuse to engage. Similarly, the earnings potential for a hopeful career path is a key individual variable, given substantial variation in compensation among various jobs. To this end, the application should allow sufficient customization options and suitable interface to be inclusive (Salampasis \& Mention, 2018). While modeling these individual-level variables complicates an already complex problem, the benefits to informed investment decisions are potentially enormous.

\section{Right Time}

Financial literacy in young adults is decidedly poor with most high-school students reporting high confidence in finance yet scoring objectively low on financial literacy assessments (Lusardi et al., 2010). To further compound the issue, the adolescent brain is immature and biologically predisposed to favor "emotional" decisions over "rational" ones (Casey et al., 2008; Reyna \& Farley, 2006). The higher-order cognitive skills needed for complex decisions, such as hypothetical thought are not fully developed until early adulthood (Giedd, 2008; Johnson et al., 2009). This maturation pattern requires that adolescents make consequential human capital investment decisions when they are underprepared, over confident, and developmentally distant from "homo economicus" (see Braun (2021) for a summary of this term).

While an application cannot speed development of the adolescent brain, it can offer information based on best-practices in the financial education field. Financial knowledge is particularly sensitive to time decay, so presenting appropriate information just-in-time is essential (Fernandes et al., 2014). However, just-in-time interventions are more effective when targeted at specific behaviors (Carlin \& Robinson, 2012; Drever et al., 2015; Grinstead et al., 2011). Choi et al. (2016) assert a need for comprehensive financial coaching rather than tackling one interlinked issue after another. However, a just-in-time approach within a comprehensive framework requires trade-offs between theoretical purity and accessibility. 


\section{METHODS}

A comprehensive education-career investment model must incorporate research-based parameters to facilitate estimation of a lifetime net present value (NPV). While others outline comprehensive lifetime models (Cunha et al., 2006, among others) we structure our model for individual-level application focusing on financial returns to an education-career investment, ceteris paribus, save for adjustments based on individual preferences. We begin with an adaptation of Becker's (1962) equation 5:

$G=E_{i}\left[\sum_{t=0}^{T} \frac{D I_{t}}{(1+d)^{t}}\right]$

where the net present value (NPV), $G$, is a function of individual expectations, $E_{i}[f(x)]$, using discretionary income, $D I_{t}$, from an education-career path applying discount rate, $d$, over $T$ periods. Given the complexity and need for dynamic updates, we opt for a hierarchical alphanumeric nomenclature to identify both equations and variables rather than a traditional numeric equation identification (see Figure 1).

FIGURE 1

ILLUSTRATION OF THE INITIAL MODEL

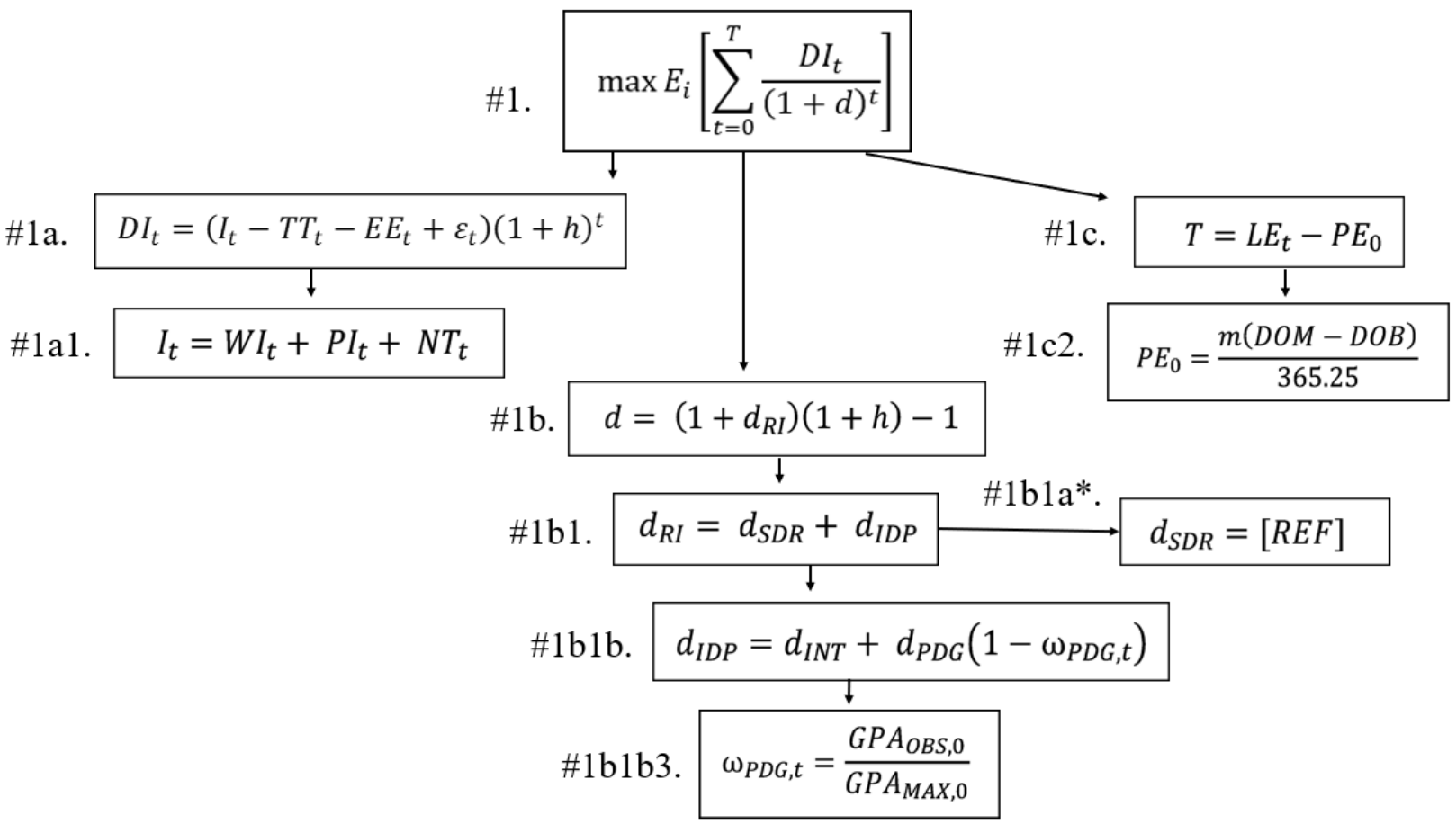

\section{Model Specification}

Table I provides the default input parameters for the initial model which is outlined in Figure 1. Variables include government-determined parameters, education plans, career goals, personal timeline, and lifestyle selections, among others. The default parameters generally reflect national averages to the extent possible. The primary goal of model specification is to improve the model with better data (Table I) and greater expertise.

\section{Implementation Requirements}

At a high level, we establish a minimal set of requirements for implementation of the human capital investment application. The initial goal is not to build out the full application, but rather a Lean Startup 
Approach (LSA) to enable engagement with prospective users (Ghezzi, 2019). Obtaining constructive feedback to steer productive FinTech development is critical, particularly when limited to a budget constrained by the resources accessible via a university technology transfer office. The following are implementation requirements of the prototype:

1. Intellectual property (IP) protection: The implementation must protect core IP leaks.

2. Familiar interface: The prototype must appear in a format that is familiar to users. This reduces the friction for onboarding new users allowing prototype deployments to focus on the capabilities of the tool rather than the interface.

3. Reasonable user experience (UX): While production-level quality UX is not required, it should nonetheless be understandable, easily readable, low latency, etc.

4. Scalable: Even at an early stage, one must factor in the ability of the approach to scale longer term. This could mean support for new features, a growing user base, or a variety of use cases.

5. Simple delivery: Delivery of the tool should minimize intervention from administrators, developers, or support staff.

6. Low cost: The system should require minimal maintenance expense to remain online and functional. Specifically, this includes keeping the software stack updated with regular operating system (OS) and tool updates so that it remains secure.

\section{RESULTS AND DISCUSSION}

The resulting prototype application at www.cashncareers.org suggests that a collaboration between academia and FinTech holds potential in developing a customizable, just-in-time human capital investment decision application. The model and default parameters with this prototype construction produce accessible and plausible human capital financial estimates.

\section{Goal 1 Result: Right Information}

We construct equations around research-based parameters and available data sources. In situations where theoretical purity conflicts with accessibility of quality data, we compromise to facilitate a functional system. While imperfect, the model uses verified data to yield projections such that the user may "off-load" many aspects of the calculation, including the tedious search for clear costs and coordination of relevant information. One key feature is the ability to account for opportunity costs, resulting in an agnostic tool that does not steer an individual toward any particular path but rather provides financial projections. We assert that while Table I includes many variables, still more variables could be reasonably included in an initial model. The volume and sourcing challenges of accessing quality parameters necessarily means that imperfect variables are included.

Given the six requirements outlined above, we implement the applied model using a cloud based serverless infrastructure. In this environment, the cloud provider professionally maintains machines, operating systems, patches, infrastructure software, etc., which are then rented out on an as-needed basis. This approach provides a high uptime, low maintenance, and highly scalable platform that can easily scale with the number of users and support more advanced features with very low up-front investment. When combined, the Table I data and application implementation offer users the right information.

\section{Goal 2 Result: Right Person}

A prototype user can adjust financial information to apply scenario or sensitivity analysis appropriate to their individual circumstances. Specifically, the model should consider how individual qualities alter the financial projections. For example, the default high-school GPA of 2.59 must be editable to reflect academic variance. As a proxy for ability, GPA propagates through the model with an adjustment to the discount rate (equation $1 \mathrm{~b} 1 \mathrm{~b} 3 *$ ), the college completion probability (equation 1ala1a $3 *$ ), and earnings potential (equation $1 \mathrm{a} 1 \mathrm{a} 2 \mathrm{a} 2 *$ ) with an end result of NPV variance given the same career selection. While this approach has much room for improvement, it does offer customizable financial and academic information - specific to the right person. 
Compared to gathering the information, allowing for customization of the information is relatively straightforward. The primary obstacle with customization is guiding users in how to make sensible adjustments. While the model incorporates the equations and default values, not all parameters are editable in the prototype. Our research team identified identify key variables to implement initially, however, we acknowledge that inclusion of additional customizable variables is a critical step going forward. Furthermore, implementation must be thoughtful to avoid UX overload.

\section{Goal 3 Result: Right Time}

In addition to the above architectural considerations (e.g., desktop and mobile access, high website uptime, etc.), we specifically optimize the system to achieve low latency response times. Our initial approach generated a variety of charts on the server side and then transmitted these to the client to display, in an attempt to minimize the amount of processing required by the client. In reality, between the processing required on the server side and the additional data transmission needed, we observed response times of about ten seconds, which is far too slow for a viable UX. The prototype implementation inverts this approach. Data for the charts is generated on the server side and semantically compressed, resulting in transmission of less than five kilobytes. The entire application programming interface (API) call takes about half a second to complete, including Secure Sockets Layer (SSL) session initiation and communication overhead. Displaying the resulting data takes less than 100 milliseconds as measured on a consumer grade laptop.

Development of a web-based tool to calculate one's NPV for their human capital investment is invaluable for the just-in-time approach to financial education and literacy. Research suggests young adults with unhealthy financial behaviors (e.g., low financial impulse control) are the most likely to consult online resources and social media for financial advice (Cao \& Liu, 2017). Accordingly, accessible human capital investment information is likely to command a premium during adolescence. Targeting adolescents with a responsive web-based tool allows delivery at the right time to best leverage the resulting financial information.

Yet, the accessibility and ease of use also presents challenges. Prototype testing indicates that while the majority of users understand the value of the tool to estimate a feasible financial future, not all users do so. Some appear to search for inputs that will increase the financial projections with little thought to the selections they are making. Upon finding a sufficiently high estimate, they appear sanguine with their financial future with seemingly no comprehension that despite disliking school their selected path requires a terminal degree. This result is concerning as the likelihood of a student with a history of academic underperformance achieving a terminal degree is quite low and, yet, consistent with the Dunning-Kruger effect where the individual lacks enough self-awareness to realize their incompetence (Kruger \& Dunning, 1999). Again, proper use of any sufficiently complicated tool may require guidance from a professional.

\section{CONCLUSION}

\section{Limitations and Future Directions}

The limitations of this model and the overall approach are many. First, we acknowledge that financial costs and benefits of human capital investment are but one aspect of the decision-making process. Even though all areas of wellness are interconnected, dollars are relatively easy to operationalize while other dimensions of wellness are generally more difficult to define and measure (Swarbrick, 2006). Second, this model also does not address a number of hard-to-quantify aspects of human capital investment and career selection. Social considerations involving human capital may include positive externalities such as more effective citizenship, greater opportunities for mate selection, or simply having fun. Value based features such as career expenses, employment benefits, or other non-wage consideration are not explicitly included in this model. The model also fails to address a number of non-monetary individual considerations such as working conditions, perceived job usefulness (Wolfe \& Patel, 2019), self-actualization or self-knowledge (Van Ewijk \& Weber, 2021), and association with a particular institution. 
Finally, this model does not explicitly address all aspects of a lifetime financial picture. Improving estimates without degrading the UX requires both the general intelligence of human experts and the specialized intelligence of smart machines, human-computer superminds (Malone, 2018). Machine learning presents a means to address, if not optimize, human interaction with a complex and dynamic model (Verbraeken et al., 2020). We also model human capital investment only in the United States as other nations have substantially different structures (see for example, Bönte \& Filipiak, 2012; Hanafizadeh et al., 2014). Refining the prototype application requires careful analysis of the trade-offs between the rigor of estimates and the UX.

\section{Implications}

This work, and other digital resources to support human capital investment decisions such as Georgetown's College ROI tool (Carnevale et al., 2019) or Init2Winit (Chen et al., 2021), point the way toward the future of personal financial planning around education investments. Potential benefits include a more invested labor force, greater labor mobility, enhanced consumer sovereignty, and increased chances of entrepreneurial success (Millan et al., 2014). Higher education is often difficult to navigate for firstgeneration college students and those with limited economic means. As such, these same individuals may benefit the most from timely information regarding human capital investments. Research suggests that those with low levels of financial literacy are likely to rely on friends and family for financial advice (who may also have low financial literacy) and are less likely to engage in proactive investment behaviors (Van Rooij et al., 2011). Instead of a challenge, this behavior could be viewed as an opportunity; individuals who have been historically underserved by traditional financial institutions may be more likely to engage with FinTech, especially if accessible using a mobile device (Salampasis \& Mention, 2018).

While the market is ripe for development of individual-level human capital investment tools (Julien \& Ross, 2020), entrepreneurial perseverance in the area is a challenge. University faculty versed in research, modeling, and having close student interaction may be the most capable of developing such a tool, yet university resources and tech transfer funding exists in a complex milieu of administration, admission quotas, and transparency mandates. This pre-emergence venture is so closely tied to the university mission it requires a high degree of opportunity confidence (Dimov, 2010). Given the amplified potential for agency conflict, maintaining the emotional energy needed to persevere is critical (Walsh et al, 2020). Despite these substantial challenges, we assert that a human capital investment robo-advising platform holds great promise for those eager to explore a unique project - their own human capital investment.

\section{ACKNOWLEDGEMENTS}

Students of Dr. Muhammad Razi provided initial software design elements. Students of Dr. Alhassan Mumuni provided preliminary marketing research and strategy input. We are grateful to staff members at Western Michigan University's Office of Research and Innovation. Todd Mora, Jim DeMello, Onur Arugaslan, Jamie Weathers, and other affiliates of the Sanford Center for Financial Planning and Wellness provided invaluable input. The Kalamazoo Promise and the Michigan Association of State Universities provided letters of support. Finally, we thank the hundreds of WMU students that provided user feedback during Cash ' $n$ ' Careers development. Conference presentations and grant submissions under related titles have included elements of this work (see Ross, Wright, and DeMello (2019) for an example). Financial support to develop the Cash ' $n$ ' Careers application came from the Michigan Economic Development Corporation (MEDC) sponsored ADVANCE Grant Proof-of-Concept Fund, a Western Michigan University (WMU) faculty research and creative activities award (FRACAA), a Sanford Center for Financial Planning and Wellness matching funds grant, and the Western Michigan University Research Foundation Technology Development Fund. Initial customer discovery was supported by a Michigan Tech I-Corps NSF Site mini-grant. Additional faculty support came from the Haworth College of Business Dean's Summer Research Fellowship. Western Michigan University owns the Cash 'n' Careers tool under intellectual property (IP) disclosure \#2018-002. 


\section{REFERENCES}

Abel, J.R., \& Deitz, R. (2014). Do the benefits of college still outweigh the costs? Current Issues in Economics and Finance, 20(3), 1-9. Retrieved from https://econpapers.repec.org/RePEc:fip:fednci:00003

Arias, E., Xu, J., \& Kochanek, K.D. (2019). United States life tables, 2016. National Vital Statistics Reports, 68(4), 1-66. Retrieved from https://www.cdc.gov/nchs/data/nvsr/nvsr68/nvsr68_04508.pdf

Autor, D.H. (2014). Skills, education, and the rise of earnings inequality among the "other 99 percent." Science, 344(6186), 843-851. https://doi.org/10.1126/science.1251868

Avery, C., \& Turner, S. (2012). Student loans: Do college students borrow too much-or not enough? Journal of Economic Perspectives, 26(1), 165-192. https://doi.org/10.2307/41348811

Bartlett, M.L., \& McCarley, J.S. (2019). Human interaction with automated aids: Implications for roboadvisors. Financial Planning Review, 2(3-4), e1059. https://doi.org/10.1002/cfp2.1059

Baum, S., Ma, J., Pender, M., \& Libassi, C. (2018). Trends in student aid. Retrieved from https://trends.collegeboard.org/sites/default/files/2018-trends-in-student-aid.pdf

Becker, G.S. (1962). Investment in human capital: A theoretical analysis. Journal of Political Economy, 70(5, Part 2), 9-49. https://doi.org/10.1086/258724

Bonn, S. (2019, February 4). Unemployment benefits comparison by state. File Unemployment. Retrieved from https://fileunemployment.org/unemployment-benefits/unemployment-benefits-comparisonby-state

Bönte, W., \& Filipiak, U. (2012). Financial literacy, information flows, and caste affiliation: Empirical evidence from India. Journal of Banking and Finance, 36(12), 3399-3414. https://doi.org/10.1016/j.jbankfin.2012.07.028

Bostwick, V., Fischer, S., \& Lang, M. (2022). Semesters or quarters? The effect of the academic calendar on postsecondary graduation rates. American Economic Journal: Economic Policy, Forthcoming

Braun, E. (2021). The institutional preconditions of homo economicus. Journal of Economic Methodology, 28(2), 231-246. https://doi.org/10.1080/1350178X.2021.1898659

Brush, C., Ali, A., Kelley, D., \& Greene, P. (2017). The influence of human capital factors and context on women's entrepreneurship: Which matters more? Journal of Business Venturing Insights, 8, 105113. https://doi.org/10.1016/j.jbvi.2017.08.001

Bui, Q., \& Miller, C.C. (2018, August 4). The age that women have babies: How a gap divides America. The New York Times. Retrieved from https://www.nytimes.com/interactive/2018/08/04/upshot/up-birth-age-gap.html

Cao, Y., \& Liu, J. (2017). Financial executive orientation, information source, and financial satisfaction of young adults. Journal of Financial Counseling and Planning, 28(1), 5-19. https://doi.org/10.1891/1052-3073.28.1.5

Caplan, B. (2018). The case against education: Why the education system is a waste of time and money. Princeton University Press. https://doi.org/10.2307/j.ctvc772xh

Carlin, B.I., \& Robinson, D.T. (2012). What does financial literacy training teach us? Journal of Economic Education, 43(3), 235-247. https://doi.org/10.1080/00220485.2012.686385

Carnevale, A.P., Cheah, B., \& Van Der Werf, M. (2019). A first try at ROI: Ranking 4,500 colleges. Retrieved from https://1gyhoq479ufd3yna29x7ubjn-wpengine.netdna-ssl.com/wpcontent/uploads/College_ROI.pdf

Casey, B.J., Jones, R.M., \& Hare, T.A. (2008). The adolescent brain. Annals of the New York Academy of Sciences, 1124(1), 111-126. https://doi.org/10.1196/annals.1440.010

Cataldi, E.F., Green, C., Henke, R., Lew, T., Woo, J., Shepard, B., \& Siegel, P. (2011). 2008-09 Baccalaureate and beyond longitudinal study. In Institute of Education Sciences. U.S. Department of Education. Retrieved from https://nces.ed.gov/pubs2011/2011236.pdf

Chatterjee, S., \& Ionescu, F. (2012). Insuring student loans against the financial risk of failing to complete college. Quantitative Economics, 3(3), 393-420. https://doi.org/10.3982/QE100 
Chen, I.C., Rocha-Beverly, C., \& Schneider, B. (2021). Alignment of educational aspirations and career plans in high school with Mobile app technology. Education and Information Technologies, 26(1), 1091-1109. https://doi.org/10.1007/s10639-020-10296-z

Choi, S., Gudmunson, C.G., Griesdorn, T.S., \& Hong, G-S. (2016). Assessing college student needs for comprehensive financial counseling. Journal of Financial Counseling and Planning, 27(2), 158171. https://doi.org/10.1891/1052-3073.27.2.158

College Board. (2019, May 25). Average rates of growth of published charges by decade. Trends in Higher Education. Retrieved from https://trends.collegeboard.org/content/average-rates-growthpublished-charges-decade- 0

Cunha, F., Heckman, J.J., Lochner, L., \& Masterov, D.V. (2006). Interpreting the evidence on life cycle skill formation. In E.A. Hanushek \& F. Welch (Eds.), Handbook of the Economics of Education (Vol. 1, pp. 697-812). Elsevier. https://doi.org/10.1016/S1574-0692(06)01012-9

Dimov, D. (2010). Nascent entrepreneurs and venture emergence: Opportunity confidence, human capital, and early planning. Journal of Management Studies, 47(6), 1123-1153. https://doi.org/10.1111/j.1467-6486.2009.00874.x

Drever, A.I., Odders-White, E., Kalish, C.W., Else-Quest, N.M., Hoagland, E.M., \& Nelms, E.N. (2015). Foundations of financial well-being: Insights into the role of executive function, financial socialization, and experience-based learning in childhood and youth. Journal of Consumer Affairs, 49(1), 13-38. https://doi.org/https://doi.org/10.1111/joca.12068

El-Sibaie. (2018, November 28). 2019 tax brackets. Tax Foundation. Retrieved from https://taxfoundation.org/2019-tax-brackets/

Eubanks, V. (2018). Automating inequality: How high-tech tools profile, police, and punish the poor. St Martin's Press.

Federal Reserve. (2019). What are the Federal Reserve's objectives in conducting monetary policy? In Money, Interest Rates, and Monetary Policy. Board of Governors of the Federal Reserve System. Retrieved from https://www.federalreserve.gov/faqs/money_12848.htm

Fernandes, D., Lynch, J.G., Jr., \& Netemeyer, R.G. (2014). Financial literacy, financial education, and downstream financial behaviors. Management Science, 60(8), 1861-1883. https://doi.org/10.1287/mnsc.2013.1849

French, M.T., Homer, J.F., Popovici, I., \& Robins, P.K. (2015). What you do in high school matters: High school GPA, educational attainment, and labor market earnings as a young adult. Eastern Economic Journal, 41(3), 370-386. https://doi.org/10.1057\%2Feej.2014.22

Ghezzi, A. (2019). Digital startups and the adoption and implementation of lean startup approaches: Effectuation, bricolage and opportunity creation in practice. Technological Forecasting and Social Change, 146, 945-960. https://doi.org/10.1016/j.techfore.2018.09.017

Giedd, J.N. (2008). The teen brain: Insights from neuroimaging. Journal of Adolescent Health, 42(4), 335-343. https://doi.org/10.1016/j.jadohealth.2008.01.007

Grinstead, M., Mauldin, T., Sabia, J.J., Moss, J.K., \& Palmer, L. (2011). Saving for success: Financial education and savings goal achievement in individual development accounts. Journal of Financial Counseling and Planning, 22(2), 28-40. https://doi.org/10.2139/ssrn.1996707

Hanafizadeh, P., Behboudi, M., Koshksaray, A.A., \& Tabar, M.J.S. (2014). Mobile-banking adoption by Iranian bank clients. Telematics and Informatics, 31(1), 62-78. https://doi.org/10.1016/j.tele.2012.11.001

Hayes, D., Cappa, F., \& Le-Khac, N.A. (2020). An effective approach to mobile device management: Security and privacy issues associated with mobile applications. Digital Business, 1(1). https://doi.org/10.1016/j.digbus.2020.100001

Heckman, S.J., \& Letkiewicz, J.C. (2021). Navigating risky higher education investments: Implications for practitioners and consumers. Journal of Financial Counseling and Planning, 32(1), 1-15. https://doi.org/10.1891/JFCP-18-00002

Internal Revenue Service. (2019, May 25). Topic 751 - social security and medicare withholding rates. Tax Topics. Retrieved from https://www.irs.gov/taxtopics/tc751.html 
Johnson, S.B., Blum, R.W., \& Giedd, J.N. (2009). Adolescent maturity and the brain: The promise and pitfalls of neuroscience research in adolescent health policy. Journal of Adolescent Health, 45(3), 216-221. https://doi.org/10.1016/j.jadohealth.2009.05.016

Julien, T.L., \& Ross, M.M. (2020). Cash ' $n$ ' Careers venture analysis report. https://doi.org/10.2139/ssrn.3568767

Kraft, J.C. (2012, November 8). How far apart should you space your kids. Forbes. Retrieved from https://www.forbes.com/sites/learnvest/2012/11/08/how-far-apart-should-you-space-yourkids/\#31253fbe1b76

Kruger, J., \& Dunning, D. (1999). Unskilled and unaware of it: How difficulties in recognizing one's own incompetence lead to inflated self-assessments. Journal of Personality and Social Psychology, 77(6), 1121-1134. https://doi.org/10.1037//0022-3514.77.6.1121

LaFave, A., Kelly, E., \& Ford, J. (2018). Factors that influence student college choice. In Data Point NCES 2019-119. ERIC. Retrieved from https://nces.ed.gov/pubs2019/2019119.pdf

Lino, M., Kuczynski, K., Rodriguez, N., \& Schap, T. (2017). Expenditures on children by families, 2015. In Miscellaneous Publication No. 1528-2015. Retrieved from https:/www.cnpp.usda.gov/sites/default/files/expenditures_on_children_by_families/crc2015.pdf

Lobo, B.J., \& Burke-Smalley, L.A. (2017). An empirical investigation of the financial value of a college degree. Education Economics, 26(1), 78-92. https://doi.org/10.1080/09645292.2017.1332167

Loughead, K., \& Wei, E. (2019, May 25). State individual income tax rates and brackets for 2019. Tax Foundation. Retrieved from https://taxfoundation.org/2019-state-individual-income-tax-ratesbrackets/

Lusardi, A., Mitchell, O.S., \& Curto, V. (2010). Financial literacy among the young. Journal of Consumer Affairs, 44(2), 358-380. https://doi.org/10.1111/j.1745-6606.2010.01173.x

Ma, J., Baum, S., Pender, M., \& Libassi, C. (2018). Trends in college pricing. Retrieved from https://trends.collegeboard.org/sites/default/files/2018-trends-in-college-pricing.pdf

Malone, T.W. (2018). How human-computer 'Superminds' are redefining the future of work. MIT Sloan Management Review, 59(4), 33-41. Retrieved from https://ilp.mit.edu/media/news_articles/smr/2018/59423.pdf

Millán, J.M., Congregado, E., Román, C., Van Praag, M., \& Van Stel, A. (2014). The value of an educated population for an individual's entrepreneurship success. Journal of Business Venturing, 29(5), 612-632. https://doi.org/10.1016/j.jbusvent.2013.09.003

Moore, M.A., Boardman, A.E., Vining, A.R., Weimer, D.L., \& Greenberg, D.H. (2004). "Just give me a number!" Practical values for the social discount rate. Journal of Policy Analysis and Management, 23(4), 789-812. https://doi.org/10.1002/pam.20047

Moreno, T. (2018, December 3). US cities that levy income taxes. The Balance. Retrieved from https://www.thebalance.com/cities-that-levy-income-taxes-3193246

Muñoz, P., \& Dimov, D. (2015). The call of the whole in understanding the development of sustainable ventures. Journal of Business Venturing, 30(4), 632-654. https://doi.org/10.1016/j.jbusvent.2014.07.012

Natarajan, S., \& Nasiripour, S. (2019, November 9). Viral tweet about apple card leads to Goldman Sachs probe. Bloomberg. Retrieved from https:/www.bloomberg.com/news/articles/2019-11-09/viraltweet-about-apple-card-leads-to-probe-into-goldman-sachs

Newport, F. (2019, May 8). Snapshot: Average American predicts retirement age of 66. Gallup. Retrieved from https://news.gallup.com/poll/234302/snapshot-americans-project-average-retirementage.aspx

Obermeyer, Z., Powers, B., Vogeli, C., \& Mullainathan, S. (2019). Dissecting racial bias in an algorithm used to manage the health of populations. Science, 366(6464), 447-453. https://doi.org/10.1126/science.aax2342

OECD. (2007). Typical graduation ages in tertiary education. In Education at a glance 2007 (p.451). https://doi.org/10.1787/eag-2007-en 
Paulsen, M.B., \& St. John, E.P. (2002). Social class and college costs: Examining the financial nexus between college choice and persistence. Journal of Higher Education, 73(2), 189-236. https://doi.org/10.1080/00221546.2002.11777141

Perna, L. W., Wright-Kim, J., \& Jiang, N. (2021). Money matters: Understanding how colleges and universities use their websites to communicate information about how to pay college costs. Educational Policy, 35(7), 1311-1348. https://doi.org/10.1177/0895904819867398

Population Reference Bureau. (2019). Median age at first marriage (women). United States Indicators. Retrieved from https://www.prb.org/usdata/indicator/marriage-age-women/snapshot

Reyna, V.F., \& Farley, F. (2006). Risk and rationality in adolescent decision making: Implications for theory, practice, and public policy. Psychological Science in the Public Interest, 7(1), 1-44. https://doi.org/10.1111/j.1529-1006.2006.00026.x

Roser, M. (2019). Fertility rate. In Our World in Data. Retrieved from https://ourworldindata.org/fertilityrate

Ross, M.M., Wright, A.M., \& DeMello, J.P. (2019). Cash 'n' Careers: Human capital investment. In D. Winchester \& A. Betz-Hamilton (Eds.), Proceedings of The Association for Financial Counseling and Planning Education ${ }^{\circledR}$ (pp. 97-103). Retrieved from https://www.afcpe.org/wpcontent/uploads/2019/11/AFCPE-Proceedings_2019_FINAL.pdf

Salampasis, D., \& Mention, A.-L. (2018). FinTech: Harnessing innovation for financial inclusion. In D.K.C. Lee \& R.H. Deng (Eds.), Handbook of Blockchain, Digital Finance, and Inclusion, Volume 2 (pp. 451-461). Elsevier. https://doi.org/10.1016/C2016-0-03679-3

Savage, S.L. (2009). The flaw of averages: Why we underestimate risk in the face of uncertainty (1st ed.). John Wiley \& Sons. https://doi.org/10.5860/choice.47-3267

Siepel, J., Cowling, M., \& Coad, A. (2017). Non-founder human capital and the long-run growth and survival of high-tech ventures. Technovation, 59, 34-43. https://doi.org/10.1016/j.technovation.2016.09.001

Social Security Administration. (2019a). Retirement planner: The difference between retirement age \& stop work age. Retrieved from https://www.ssa.gov/planners/retire/stopwork.html

Social Security Administration. (2019b). Benefits planner: Retirement. Retrieved from https://www.ssa.gov/planners/retire/r\&m6.html

Swarbrick, M. (2006). A wellness approach. Psychiatric Rehabilitation Journal, 29(4), 311-314. https://doi.org/10.2975/29.2006.311.314

Thomas, V.J., Bliemel, M., Shippam-Brett, C., \& Maine, E. (2020). Endowing university spin-offs preformation: Entrepreneurial capabilities for scientist-entrepreneurs. Technovation, 96-97, Article 102153. https://doi.org/10.1016/j.technovation.2020.102153

US Bureau of Labor Statistics. (2019a). Unemployment rate - college graduates - bachelor's degree, 25 years and over [CGBD25O]. FRED, Federal Reserve Bank of St. Louis. Retrieved from https://fred.stlouisfed.org/series/CGBD25O

US Bureau of Labor Statistics. (2019b). Unemployment rate - high school graduates - no college, 25 years and over [LNU04027660]. FRED, Federal Reserve Bank of St. Louis. Retrieved from https://fred.stlouisfed.org/series/LNU04027660

US Bureau of Labor Statistics. (2019c). Average (Mean) Duration of Unemployment [UEMPMEAN]. FRED, Federal Reserve Bank of St. Louis. Retrieved from https://fred.stlouisfed.org/series/UEMPMEAN

US Census Bureau. (2018). PINC-03. Educational attainment--people 25 years old and over, by total money earnings in 2017, work experience in 2017, age, race, Hispanic origin, and sex. Retrieved from https://www.census.gov/data/tables/time-series/demo/income-poverty/cps-pinc/pinc-03.html

US Department of Education. (2019a). Standard plan. Office of Federal Student Aid. Retrieved from https://studentaid.ed.gov/sa/repay-loans/understand/plans/standard

US Department of Education. (2019b). Subsidized and unsubsidized loans. Office of Federal Student Aid. Retrieved from https://studentaid.ed.gov/sa/types/loans/subsidized-unsubsidized\#interest-rates

60 Journal of Applied Business and Economics Vol. 23(8) 2021 
US Department of Labor. (2012). Fact Sheet \#28: The Family and Medical Leave Act. Wage and Hour Division. Retrieved from https:/www.dol.gov/agencies/whd/fact-sheets/28-fmla

US Department of Labor. (2019, May 29). Minimum wage laws in the States. Wage and Hour Division. Retrieved from https://www.dol.gov/whd/minwage/america.htm

Van Ewijk, A.R., \& Weber, W. (2021). The value of knowing what you want: Goal hierarchy and entrepreneurial intentions. Journal of Business Venturing Insights, 15, e00215. https://doi.org/10.1016/j.jbvi.2020.e00215

Van Rooij, M., Lusardi, A., \& Alessie, R. (2011). Financial literacy and stock market participation. Journal of Financial Economics, 101(2), 449-472. https://doi.org/10.1016/j.jfineco.2011.03.006

Velez, E.D., \& Horn, L. (2018). What high schoolers and their parents know about public 4-year tuition and fees in their state. In Stats in Brief NCES 2019-404. ERIC. Retrieved from https://nces.ed.gov/pubs2019/2019404.pdf

Verbraeken, J., Wolting, M., Katzy, J., Kloppenburg, J., Verbelen, T., \& Rellermeyer, J.S. (2020). A survey on distributed machine learning. ACM Computing Surveys, 53(2), 1-33. https://doi.org/10.1145/3377454

Walsh, C., Knott, P., \& Collins, J. (2020). Emotional energy and opportunity confidence. Journal of Business Venturing Insights, 13(C). https://doi.org/10.1016/j.jbvi.2019.e00155

Warner, J.T., \& Pleeter, S. (2001). The personal discount rate: Evidence from military downsizing programs. American Economic Review, 91(1), 33-53. https://doi.org/10.1257/aer.91.1.33

Washer, K., \& Nippani, S. (2004). Human capital and the balance sheet. Journal of Financial Counseling and Planning, 15(1), 13-20. Retrieved from https://ssrn.com/abstract=2256593

Webber, D.A. (2014). The lifetime earnings premia of different majors: Correcting for selection based on cognitive, noncognitive, and unobserved factors. Labour Economics, 28, 14-23. https://doi.org/10.1016/j.labeco.2014.03.009

Weckowska, D.M. (2015). Learning in university technology transfer offices: Transactions-focused and relations-focused approaches to commercialization of academic research. Technovation, 41-42, 62-74. https://doi.org/10.1016/j.technovation.2014.11.003

Wightman, P., Schoeni, R., \& Robinson, K. (2012). Familial financial assistance to young adults. Ann Arbor, MI: National Poverty Center Working Paper Series, 12-10. Retrieved from http://npc.umich.edu/publications/u/2012-10 NPC Working Paper.pdf

Wolfe, M.T., \& Patel, P.C. (2019). Exploring the differences in perceptions of work importance and job usefulness to society between self-employed and employed individuals. Journal of Business Venturing Insights, 12, e00146. https://doi.org/10.1016/j.jbvi.2019.e00146

Wright, A.M., \& Ross, M.M. (2021). Human capital investment for adolescents: Barriers and opportunities. Journal of Financial Counseling and Planning, 32(3), 387-401. https://doi.org/10.1891/JFCP-19-00088 


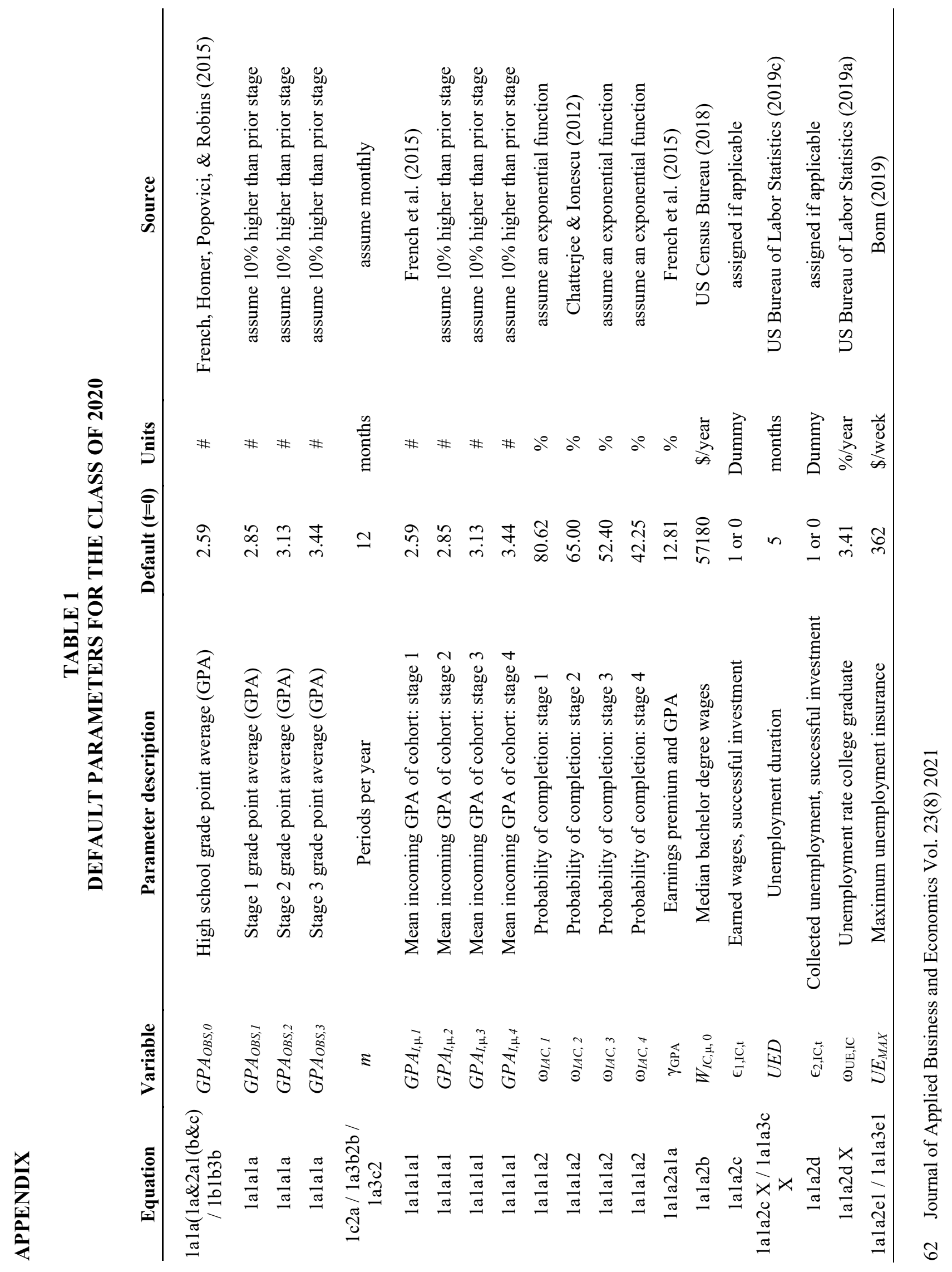




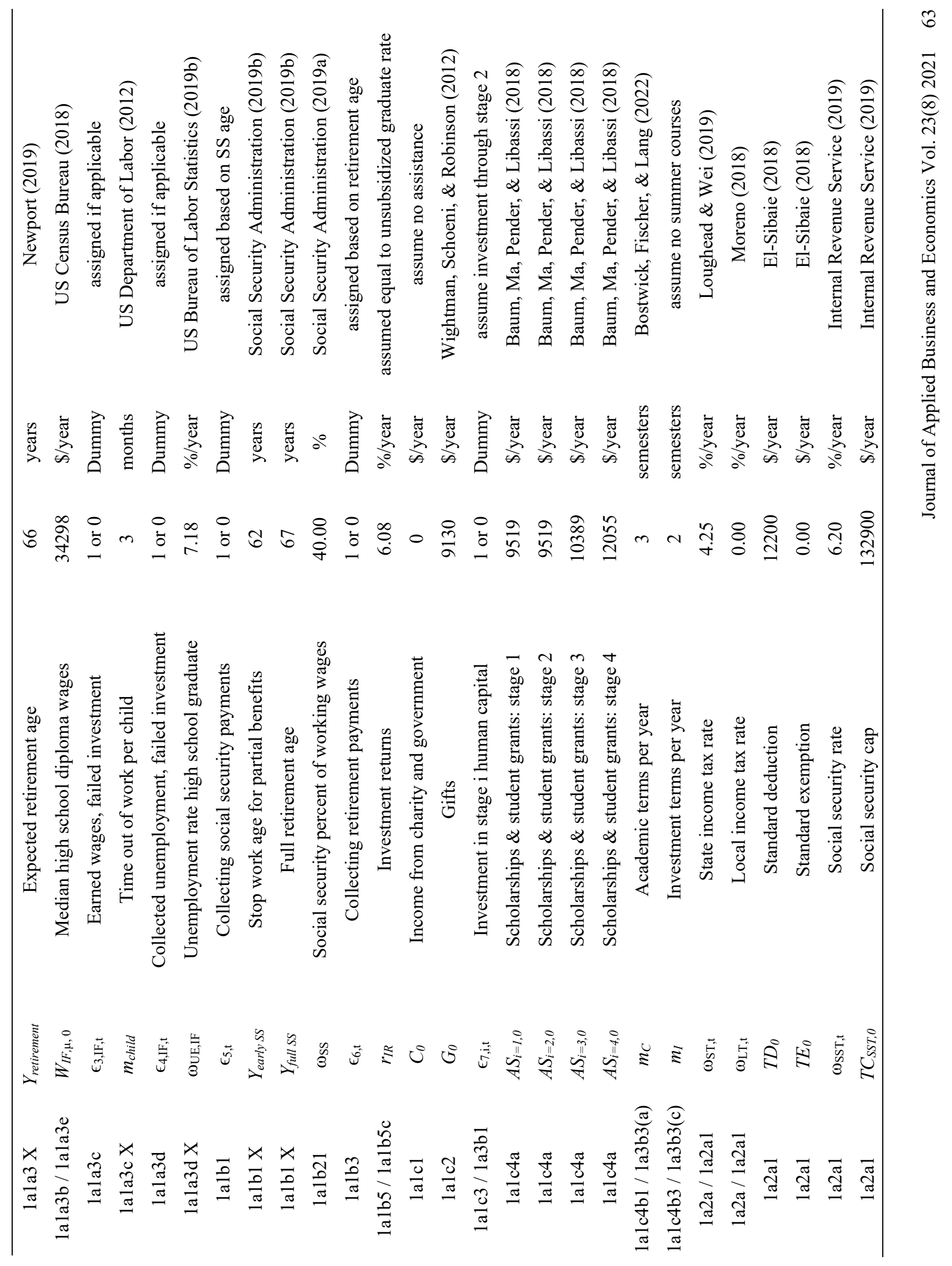




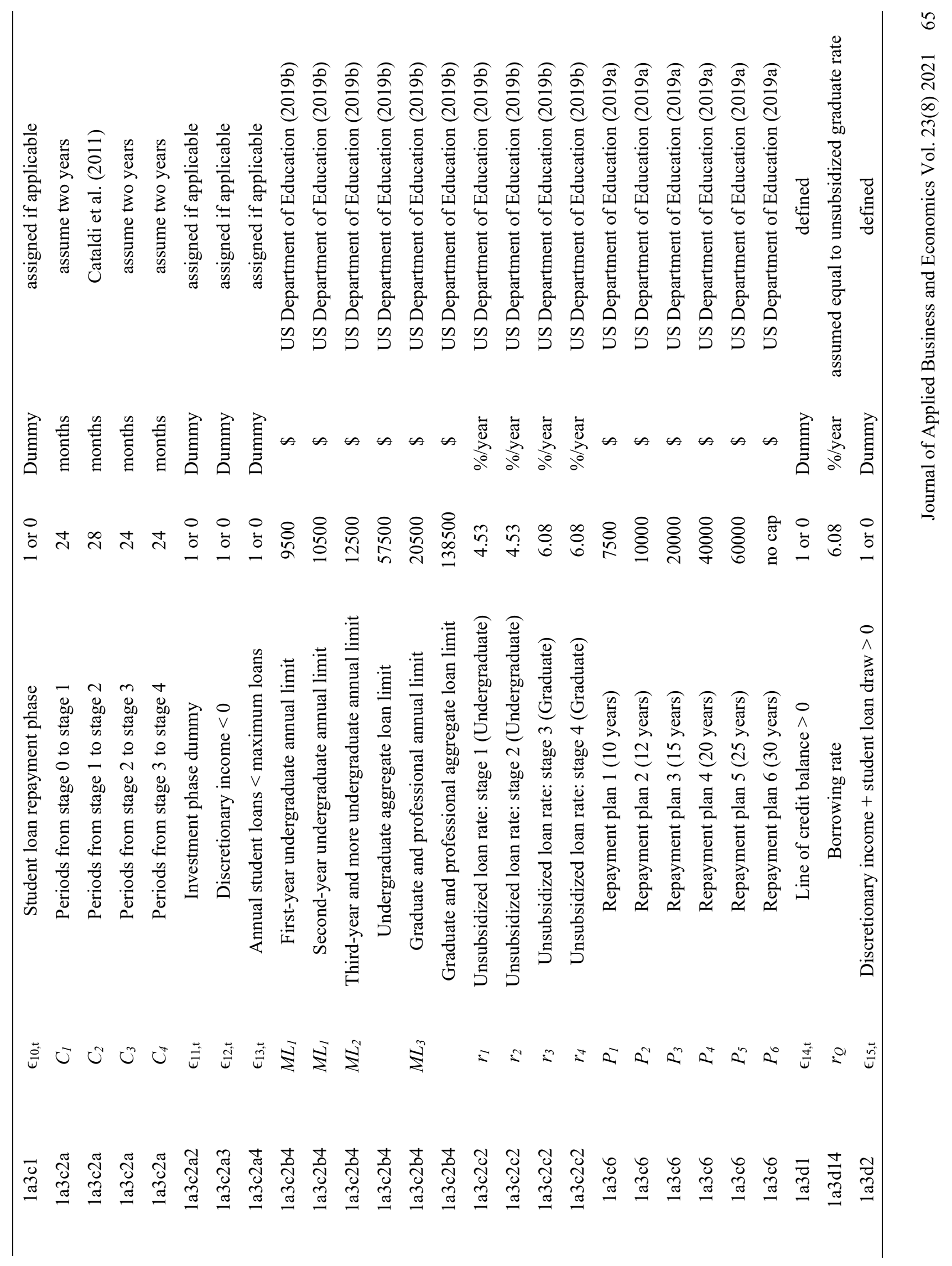




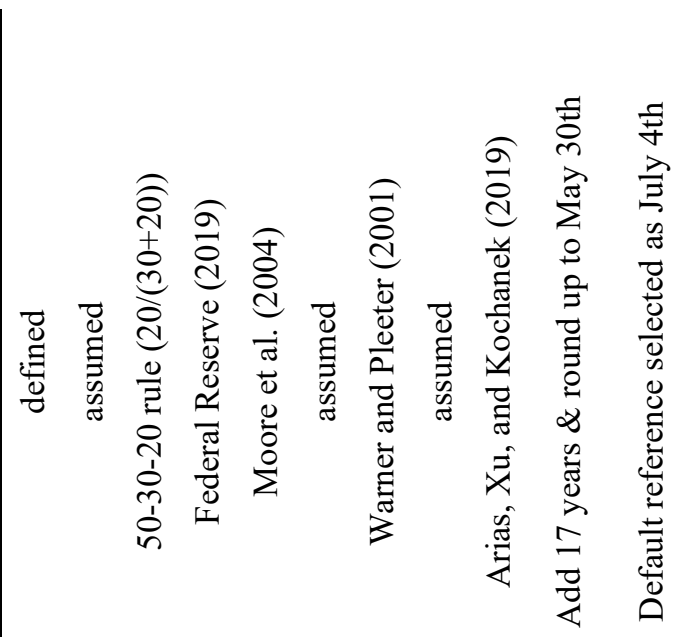

$$
\begin{aligned}
& \text { 音。゚ }
\end{aligned}
$$

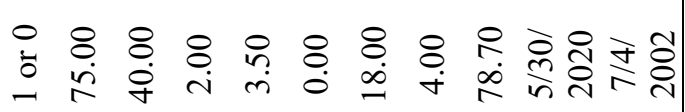

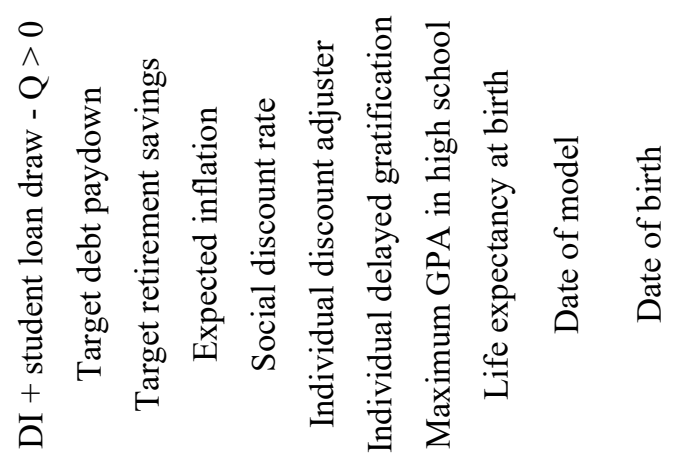

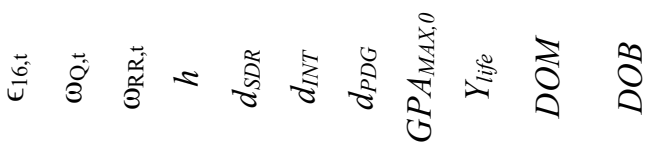

$$
\begin{aligned}
& \text { 疍 }
\end{aligned}
$$

